\title{
Comparative Study of Levels of Academic Self Esteem and Academic Achievement in Mathematics among Pupils of Two and Single Parent Families
}

\author{
Unamba, E., C1 , Okwara-Kalu, C. E' ., \& Ibe Georgeline. C. ${ }^{3}$ \\ ${ }^{1}$ Department of Primary Education Studies, Alvan Ikoku Federal College of Education, Nigeria \\ ${ }^{2}$ Department of Educational Psychology/G/C, Alvan Ikoku Federal College of Education, Nigeria \\ ${ }^{3}$ Department of Basic Science, Alvan Ikoku Federal College of Education, Owerri, Nigeria \\ *Corresponding author: unambaec@yahoo.com | Phone Number: 08038956166
}

\section{ARTICLE HISTORY}

Received : 22 March 2020

Revised : 18 July 2020

Accepted : 21 September 2020

\section{KEYWORDS}

\section{Self-esteem;}

Academic achievement;

Mathematics and two and

single parent families;

\begin{abstract}
The study aimed at comparing levels of academic self-esteem and academic achievement in mathematics among students of two and single parent families. Based on the purposes of the study two research questions and two null hypotheses were formulated and tested at 0.05 level of significance. The design of the study was comparative survey research design. The population of the study comprised all 1,267 SS2 students in Owerri Municipal Council Area of Imo State. The instruments used for data collection were Academic Self Esteem Questionnaire (ASEQ) and Mathematics Achievement Test (MAT) to obtain relevant data. The validity of the instruments was done by experts in Measurement and Evaluation and one expert each from Educational psychology and Mathematics Education. The reliability of the instruments was 0.72 and 0.85, determined using Pearson Product Moment Correlational (PPMC) statistics were used. Data collected were analyzed using t-test at 0.05 level of significance. There is a statistically significant difference in levels of academic self-esteem and academic achievement in mathematics among students from single parent families and those from two parent families.
\end{abstract}

This is an open access article under the CC-BY-SA license.

\section{INTRODUCTION}

Education is universally recognized as the most effective tool of bringing desirable change towards the social and economic betterment $\&$ cultural transformation of a society in the status of human being and the country as a whole. It broadens the mental horizon of the human being. In one hand, education develops the total personality of the learner and on the other hand education contributes to the growth and development of society. It is only through education that the moral ideas, spiritual values, the aspiration of the nation and its cultural heritage are transformed from one generation to another for preservation, purification and sublimation into higher culture. To be able to guarantee all these, the curriculum content of education is usually well planned and various subjects are taught. These subjects help to equip students with knowledge, skills, and attitudes necessary for their development and for their suitable living in the society. In schools, one of the subjects taught is mathematics.

Mathematics is fundamental to national prosperity in providing tools for understanding science, engineering technology and economics. It is essential in public decision making and for participation in the knowledge economy. Mathematics is an important component of school education in the modern world. It is used in almost every phases of human life. A strong background in mathematics is crucial for many career $\&$ job opportunities in today's increasingly technological society. Mathematics holds a unique place in every society today. Students accept the fact that mathematical is vital to the continued growth of the nation, both for expanding internal advancement and maintenance of leading role in the world community. Mathematics aids students in his understanding of the world, he lives and in turn, modifies the worlds and his needs as he continues to develop (Niswah, 2020; Nufus, 2020; Nuraina, 2018). It has played a decisive role in building civilization of a nation. One of the aims of teaching mathematics in schools is to inculcate the skills of quantification of experiences around the learners. The knowledge of mathematics help learners to view themselves as active and capable learners whom can promote changes through effort and set higher goals to achieve learning new things. Numerous researchers have opined that skills such as critical thinking, problem solving, science process skills, value-orientation and creativity derived from mathematics knowledge increase learners' academic self-esteem.

Academic self-esteem is an internal belief that a student's possesses about one's self in education. Branden 1969 in Parisa (2011) defined academic self-esteem as a standard by which a student's judges her/himself, an estimate, a feeling, and an emotion. This self-evaluation is the single most significant key to behaviour, which affects the thinking processes, emotions, desires, values, and goals. It refers to an individual's sense of 
his or her value or worth, or the extent to which a student's values, approves of, appreciates, prizes, or likes him or herself in academics (Blascovich \& Tomaka, 2004). It includes beliefs as to whether he or she can expect success or failure, how much effort should be put forth, whether failure at a task will "hurt," and whether he or she will become more capable as a result of difficult experiences (Coopersmith, 1967, 1981 in Parisa, 2011).

Academic Self-esteem begins to develop early in life (Shokraii, 2000). According to Robins and Trzesniewski (2005), on average, self-esteem is relatively high in childhood, drops during adolescence, rises gradually throughout adulthood, and then declines sharply in old age. Academic self- esteem emerges when children compare their self-evaluation with actual performance on a variety of tasks (Aryana, 2010). According to Harris (2009), some researchers argue that students who perform higher in school possess positive academic self-esteem, while others argue that academic self-esteem is necessary pre-requisite for academic achievement. It has been claimed that high academic self-esteem facilitates academic achievement (Aryana, 2010; Harris, 2009).

Academic Achievement is the stage of attainment by the students, generally expressed in terms of grade or scores. It is defined as performance of students in tests based on scores. Academic achievement is used to measure the degree of mastery of skills, fundamental concepts, process, and general knowledge of subject. According to Tenaja (2014) Academic achievement refers to performance in a particular subject or in the whole curricular that is measured by school examination or test. Studies have shown that students performed better academically and had more positive school attitudes if they had parents who were aware, knowledgeable and involved in their academics (Anthony \& Walshaw, 2007). Rich learning environments that incorporate meaningful mathematical experiences are associated with higher achievement and genuine home/school collaboration has also been found to lift children's achievement significantly (Biddulph, Biddulph \& Biddulph, 2003). Results from a study conducted by Cai (2003) indicated that positive behaviours, emotional development and good academic achievement is found among students that have positive relationship with their family.

Family is the basic socialization agent for the children. Benokraitis (2011) defines family as a unit of two or more people who are related by blood, marriage or adaption and, when live together, form an economic unit and bear and raise children." A family also shares a common habitat and well defined rules for their interaction. Burgess \& Lock 1998 in Afzal \& Afzal (2016) defines family as a group of persons united by the ties of marriage, blood or adoption, constituting a single household, interacting and intercommunicating with each other in their respective social role of husband and wife, mother and father, brother and sister creating a common culture. Also Mintz \& Kellogg (2014) defines family in these terms as a group characterized by common residence, economic cooperation and reproduction. It includes adult of both sexes at least two of whom maintain a socially approved sexual relationship and one or more of their children or their own or adopted by the sexually cohabiting adult. There are different types of family namely; two parents and single parents.

Two-parent family is a family with both parents and children intact. Michelle (2012) describes it as the traditional type of family, which is held in esteem by society as it is considered the ideal to raise children. In two parent family the training as well as development of the children is high as both parents are available. In other words, children in two-parent family enjoy more parental support financially, socially and physically from both parents (Fagan \& Churchill, 2012) since both parents have more access to employment, income and savings (Amato, 2005). Two-parent families are able to give more time, affection, and supervision to their children (Peter, 2016) as the two parents can relieve one another when they find that parenting is becoming difficult (Peter, 2016). This kind of family is also likely to offer more social and emotional supports as the children would be exposed to both father- and mother-figures that are for effective socio-psychological developments. According to Ella, Odok and Ella (2015), two parents' family is held in esteem by society as being the ideal in which to raise children. In their opinion, such children receive strength and stability from the two parents' structure and generally have more opportunities due to financial ease of two parents and they tend to fare better on a number of cognitive, emotional and behavioural needs.

Also Wilkins 1976 in Afzal \& Afzal (2016) emphasized that in two parent family favourable learning environment is created, while Adika 1987 in Adesehnwa (2013) noted that conflicts are relatively easier to solve in the two parent families while Single-parent family is a separated family where a single individual bears virtually all of the daily and regular responsibilities of bringing up a child or children. Such parenting may result from death or imprisonment of a partner, separation or divorce of married parents and unintended pregnancy, especially among adolescents. It may also happen as a result of deliberate choice. In other words, individuals (especially, single women) often seek an anonymous or known sperm donor in order to get pregnant and become single mothers. Billings (2012) argues that children from such homes become delinquent because they are most often denied security, protection and love that should come from both parents and these affect their academic activities negatively. In the same vein, Stone (2012) claims that children from single parents are more likely to show, to a large extent, the effect of under-nourishment, illness, insufficient rest as well as negative attitude towards school, which manifest in infancy, which is a factor that can affect achievement and performance negatively. Single parent families have on the average, lower income are therefore, more constrained in ensuring adequate financial resources to meet their children's learning needs. It is usually more difficult for single parents to provide and maintain a supportive learning environment for their children since they must cope with the double responsibility of work and child rearing (OECD/UNESCO, 2003). Students from single-parent are more likely to exhibit problem behaviours and depressive symptoms and are less likely to display social competence (Moore,Vandivere \& Redd, 2006). Most common problems seen in single parent families children are depression, stress, loneliness, aggression, compliance, smoke, alcohol, narcotics (Herwing, Wirtz \& Bengel, 2004; Jackson, 2000; Mursalin, 2019).

The study of Hetherington (2003) found that children in divorced and remarried families show higher levels of depression and anxiety, and lower levels of academic self-esteem compared to children in non-divorced families. These findings are collaborated by the study of Elfhag, Tynelius and Rasmussen (2010) who also found out those children from single parent families had lower self-esteem compared to those raised by both parents. Amato and Keith (1991) indicated that academic self-esteem of children from single parent families is lower than that of children from two parent families while Papalia et al, 1999 indicated that academic self-esteem in 
children largely depends on the relationship between a child and the parent(s). The study of McKay and Fanning (2000); Manassis (1996) and Canadian Mental Health Association (2011) shows that level of self-esteem depends on several parental factors, not just whether the child grows in a single or two parent family. His study asserts that developing children's academic self-esteem begins with the life of the parents. Akinleke (2017) investigated impact of family structure (single and two parent families) on the academic performance of secondary school students in Yewa local government Area of Ogun State. Result of the study showed that a significant difference in the academic performance of students from single parent families and those from two parent families. Adesehinwa (2013) investigated effect of family type on students' academic achievement in Nigeria. Results showed that significant relationship exists between academic achievement, family type and students' academic motivation ( $\mathrm{r}=0.26$ : $\mathrm{P}<0.005)$. Also, a significant relationship existed in the overall academic achievement of students from monogamous families and those from polygamous families ( $\mathrm{T}-\mathrm{cal}=3.48$; $\mathrm{P}<0.005$ ).

Amadu and Moses (2013) examined influence of single parenting on pupils' academic performance in basic schools in the Wa Municipality. Results showed that there is a significant difference between the academic performance of pupils from single parent homes and those from two parent homes. James (2016) investigated influence of type of single parenthood influences a student's self-esteem from selected schools in Nakuru Municipality, Kenya. Findings of the study indicated that there is no statistically significant relationship between the type of single parenthood and the levels of students' self-esteem $(p>0.05)$. This then implies that effect on the self-esteem of students in a single parenthood setup does not depend on the cause of the absent parent. The main conclusion drawn from the study is that single parenting has negative impact on a child's academic performance. Anyakoha (2016) examined Single Parenting as Correlate of Academic Performance of Students in Unity Secondary School in South East Geo-Political Zone in Nigeria. It was found out among others that despite the financial status of single parent, they support and assist their children educationally. Hakan (2013) compare behavioral tendencies such as assertiveness, aggressiveness and submissiveness of single parent children and normal parent children who have two parents. Results showed that the single parent children are less assertive and more aggressive and submissive than their two parent peers. Therefore, this study intends to compare levels of academic self-esteem and academic achievement in mathematics among two and single parent family.

\section{Purposes of the Study}

The main purpose of this study was to compare levels of academic self-esteem and academic achievement of two and single parent families. Specifically, the study sought to:

1) Compare the mean ratings of academic self-esteem in mathematics among students of single families and two parents' families.

2) Compare the mean academic achievement scores in mathematics among students of single and two parents.

\section{Research Questions}

The following research questions guided the study:

1) What are the mean ratings of academic self-esteem in mathematics among students of single and two parents' families?
2) What is the level academic achievement scores in mathematics among students of single and two parents' families?.

\section{Hypotheses}

The following research hypotheses were tested at 0.05 level of significance.

$\mathrm{Ho}_{1}$ : There is no significant difference in the academic self-esteem mean ratings of students in mathematics from single parent families and those from two parent families?.

$\mathrm{Ho}_{2}$ : There is no significant difference in the mean achievement scores of students in mathematics from single parent families and those from two parent families?.

\section{RESEARCH METHODS}

The study design adopted for this study is comparative research survey method. This design was considered suitable for the study because it gives the researchers the opportunity of obtaining the opinion of the sampled population to infer the opinion of the entire population. The population of the study comprised all 1,267 SS2 students in Owerri Municipal council Area of Imo State. A sample of 753 secondary school students was used for the study while simple random sampling technique was used in selecting the students. The instruments used for data collection were Academic Self-Esteem Questionnaire (ASEQ) and Mathematics Achievement Test (MAT). The ASEQ was designed to measure pupils' level of academic self-esteem. The questionnaire comprised two sections, A (demographic data) and B (items on academic self-esteem). Section B presented respondents with favourable or unfavourable statements. The respondents were required to indicate either "Yes" or "No" as response. A favourable "Yes" answer to each question scored 1 and whereas an unfavorable "No" answer scored 0. Reverse items were reverse-scored. Hence, the maximum score was 20 and minimum 0 . Low scores implied low academic self-esteems and high scores implied high academic self-esteem respectively. A classification of the range of scores for academic self-esteem was 0-10 (low academic self-esteem) and 11-20 (high academic self-esteem while MAT is made 50-item objective test questions drawn from the topic 2dimensional and 3- dimensional shapes. The construction of the test instrument was guided by a table of specification and 100 percent. Therefore, the researchers classified the scores for academic achievement as follows: 0-40 (Low academic performance); 41-70 (Moderate academic performance) and 71-100 (High academic performance). A high score on academic performance denotes high performance while a low score implied low performance. For face and content validity of the instruments, it was given to two experts in Educational Psychology and one expert each from Mathematics Education and Measurement and Evaluation to certify that the instruments measures what it purports to measure. They suggested certain changes which were duly affected. They afterwards collectively agreed that the instruments would in all probability, measure what it purports to measure. To ensure reliability, test re-test of the instrument was carried out two weeks apart on 30 students. The obtained correlation coefficient was 0.72 for ASEQ and 0.70 for MAT. Data collected were analyzed using Descriptive statistics for the research questions while t-test was used to test the hypotheses at a 0.05 significance level. 


\section{RESULTS AND DISCUSSION}

\section{Results}

Research Question 1: What is the level of the mean rating of academic self esteem in mathematics among students of single and two parents' families ?.

Table 1. Mean and Standard on Academic self esteem in mathematics among students of single and two parents' families?

\begin{tabular}{|c|c|c|c|c|}
\hline Variable & Family Type & Mean & $\mathrm{Sd}$ & Mean Difference \\
\hline Acdemic & Single Parents & 60.35 & 1.23 & \\
\hline Self Esteem & Two Parents & 67.67 & 1.42 & 7.32 \\
\hline
\end{tabular}

Results in table 1 shows that the level of academic self-esteem in mathematics for single parent family is 60.35 with standard deviation of 1.23 while two parent families is 67.67 with standard deviation of 1.42 . The difference in mean scores of 7.32 was recorded in favour of two parent families.

Research Question 2: What is the level academic achievement scores in mathematics among students of single and two parents' families?.

Table 2. Mean and Standard on Academic Achievement in mathematics among students of single and two parents' families?

\begin{tabular}{ccccc}
\hline Variable & Family Type & Mean & Sd & $\begin{array}{c}\text { Difference In } \\
\text { Mean }\end{array}$ \\
\hline $\begin{array}{c}\text { Acdemic } \\
\text { Achievement }\end{array}$ & Single Parents & 64.55 & 1.23 & \\
\cline { 2 - 4 } & Two Parents & 77.17 & 1.42 & 12.62 \\
\hline
\end{tabular}

Results in table 1 shows that the academic achievement scores in mathematics for single parent family is 64.55 with standard deviation of 2.53 while two parent families is 77.17 with standard deviation of 3.12. The difference in mean scores of 12.62 was recorded in favour of two parent families.

\section{Hypotheses testing}

Ho1: There is no significant difference in the self esteem mean ratings of students in mathematics from single parent families and those from two parent families?

Tale 1: t-test analysis on self esteem in mathematics from single parent families and those from two parent families ?.

\begin{tabular}{|c|c|c|c|c|c|c|c|}
\hline Varibles & $\mathrm{N}$ & Mean & $\mathrm{Sd}$ & Df & T-Cal & T-Tab & Decision \\
\hline Sigle Parent & 108 & 19.28 & 1.72 & \multirow{2}{*}{255} & \multirow{2}{*}{2.15} & \multirow{2}{*}{1.96} & Reject \\
\hline Two Parent & 149 & 13.73 & 1.82 & & & & Ho \\
\hline
\end{tabular}

The results of the t-test presented in table 1 shows the calculated $t$-value of 2.15 is significant at $(\mathrm{P}<0.05)$ the null hypothesis is rejected and the researchers concludes that there is significant difference in the self esteem mean ratings in mathematics from single parent families and those from two parent families.

Ho2: There is no significant difference in the mean achievement scores of students in mathematics from single parent families and those from two parent families?

Tale 2: t-test analysis on Academic achievement in mathematics from single parent families and those from two parent families.

\begin{tabular}{cccccccc}
\hline Gender & N & Mean & Sd & Df & T-Cal & T-Tab & Decision \\
\hline $\begin{array}{c}\text { Single } \\
\text { Parent }\end{array}$ & 108 & 61.73 & 9.91 & 255 & 3.34 & 1.96 & $\begin{array}{c}\text { Reject } \\
\text { Ho }\end{array}$ \\
\cline { 1 - 3 } Two Parent & 149 & 51.68 & 9.33 & & & & \\
\hline
\end{tabular}

The results of the t-test presented in table 1 shows the calculated $t$-value of 3.34 is significant at $(\mathrm{P}<0.05)$ the null hypothesis is rejected and the researchers concludes that there is significant difference in the mean achievement scores in mathematics single parent families and those from two parent families ?.

\section{Discussions}

The results of the showed that students from two parent families possess high academic self esteem in mathematics than single parent families while t-test of the hypothesis indicated that there was a significant difference in level of academic self esteem in mathematics among students from single parent families and those from two parent families was accepted (P-value > 0.05). There was therefore a statistically significant comparison in level of self esteem in mathematics among students from single parent families and those from two parent families. This results is in accord with the findings of Hetherington (2003) found that children in divorced and remarried families show higher levels of depression and anxiety, and lower levels of academic self-esteem compared to children in non divorced families. Also, Elfhag, Tynelius and Rasmussen (2010) who also found out those children from single parent families had lower self-esteem compared to those raised by both parents. Amato and Keith (1991) indicated that academic self esteem of children from single parent families is lower than that of children from two parents while Hakan (2013) showed that the single parent children are less assertive and more aggressive and submissive than their two parent peers.

Also, the results of the showed that students from two parent families possess high academic achievement than single parent families while t-test of the hypothesis indicated that there was a significant difference in level of academic achievement in mathematics among students from single parent families and those from two parent families was accepted $(\mathrm{P}$-value $>0.05)$. There was therefore a statistically significant comparison in academic achievement among students from single parent families and those from two parent families. This results agreed with the findings of Akinleke (2017) investigated impact of family structure (single and two parent families) on the academic performance of secondary school students in Yewa local government Area of Ogun State. Result of the study showed that a significance difference in the academic performance of students from single parent families and those from two parent families. Adesehinwa (2013) investigated effect of family type on students' academic achievement in Nigeria. Results showed that significant relationship exists between academic achievement, family type and students' academic motivation $(r=0.26$ : $\mathrm{P}<0.005)$. Also, a significant relationship existed in the overall academic achievement of students from monogamous families and those from polygamous families (T-cal=3.48; P < 0.005). Amadu and Moses (2013) examined influence of single parenting on pupils' academic performance in basic schools in the Wa Municipality. Results showed that there is a significant difference between the academic performance of pupils from single parent homes and those from two parent homes. The main conclusion drawn from the study is that single parenting has negative impact on a child's academic performance. 


\section{CONCLUSION}

It was concluded there is significant comparison in level of academic self esteem among students from single parent families and those from two parent families. Students from two parent family generally recorded higher levels of self esteem as compared to their counterparts in single parent households but the difference was significant enough to attribute level of academic self esteem to their type of parenting. Also there is significant academic achievement in mathematics among students from single parent families and those from two parent families.

\section{Recommendations}

The following recommendations were made:

1) Parents, teachers, educational administrators, school counsellors and policy makers develop strategies to enhance academic self esteem among single parent students.

2) It is also necessary to establish and work on specific issues that students from single parent families have to contend with in order to help them enhance their level of self esteem. It is also necessary to educate parents in both single and dual parent families on the importance of academic self esteem to a student's wellbeing.

\section{REFERENCES}

Adesehinwa, O. A. (2013). Effects of family type (monogamy or polygamy) on students' academic achievement in Nigeria. International Journal of Psychology and Counselling, 5 (7), 153 - 156 DOI 10.5897/IJPC10.012 ISBN 2141-2499.

Akinleke, W., O. (2017). Impact of family structure on the academic performance of secondary school students in yewa local government area of ogun state, Nigeria International Journal of Sociology and Anthropology Research, 3(1) 1-10.

Amadu, M A. and Moses N., F. (2013). Influence Of Single Parenting On Pupils' Academic Performance In Basic Schools In The Wa Municipality. International Journal of Education Learning and Development Vol.1, No.2, pp.85-94, December 2013.

Amato, P. (2000). The Consequences of Divorce: Theories and Children. Journal of Marriage and the Family, 62, 1268 1287.

Anyakoha,C.,I.(2016). Single Parenting as Correlate of Academic Performance of Students in Unity Secondary School in South East Geo-Political Zone in Nigeria. International Journal of Technology and Inclusive Education (IJTIE), Volume 5, Issue 2, December 2016.

Aryana, M. (2010). Relationships between self-esteem and academic achievement amongst pre-university students. Journal of Applied Sciences, 10(20), 2474- 2479.

Benokraitis., N. V. (2011). Marriages and Families, Changes, Choices \& Constraint:Printice Hall New Jersey.

Biddulph, F., Biddulph, J. \& Biddulph, C. (2003).The Complexity of Community and Family Influences on Children's Achievement in New Zealand: Best Evidence Synthesis Iteration (BES). Ministry of Education. New Zealand.

Billings, W. (2012). Family Background and Students Learning Outcomes in Schools. McKini Press, Nairobi.
Blascovich, J., \& Tomaka, J. (1991). Measures of self-esteem. In J. P. Robinson, P. R. Shaver, \& L. S. Wrightsman (Eds.) Measures of personality and social psychological attitudes, Volume I. San Diego, CA: Academic Press.

Cai, J. (2003). Investigating parental roles in students' learning of mathematics from a cross-national perspective. Mathematics Education Research Journal, 15(2), 87-106.

Canadian Mental Health Association (2011) Children and self-esteem. Retrieved April 9, 2012, http://www.cmha.ca/bins/content_page.asp?cid=2-29-6 8 Dowd, Nancy, E. (1997). In Defense of Single-Parent Families. New York: New York University Press.ISBN 978-0-8147-1916-9.

Dahliana, D., Marhami, M., \& Mursalin, M. (2019). Improving Students' Mathematical Critical Thinking Abilities Through the Problem Solving Method on the Sequences and Series Course. International Journal for Educational and Vocational Studies, 1(7), 813-816.

DOI: https://doi.org/10.29103/ijevs.v1i7.2571

Elfhag, K., Tynelius, P.and Rasmussen. (2010). Self-Esteem Links in Families with 12-Year- Old Children and in Seperated Spouses. The Journal of Psychology; 144(4):341-59. Retrieved November 23, 2013 from the World Wide Web: http://www.ncbi.nlm.nih.gov/pubmed/20617762.

Ella, R.E., Odok, A.O. \& Ella, G.E. (2015). Influence of Family Size and Family Type on Academic performance of Students in Government in Calabar Municipality, Cross River State, Nigeria. International Journal of Humanities, Social Sciences and Education (IJHSSE), 2(11), 108 - 114

Hakan, U.(2013) Comparison of Single and Two Parents Children in terms of Behavioral Tendencies. International Journal of Humanities and Social Science Vol. 3 No. 8 [Special Issue-April 2013].

Harris, S. L. (2009). The relationship between self-esteem and academic success among African American students in the minority engineering program at a research extensive university in the southern portion of the United States. Unpublished Ph.D. thesis, Louisiana State University and Agricultural and MechanicalCollege.

Herwig, J. E., Wirtz, M., \& Bengel, J. (2004). Depression, partnership, social support, and parenting: Interaction of maternal factors with behavioral problems of the child. Journal of Affective Disorders, 80, 199-208.

Hetherington, M. E. (2003). Social support and the adjustment of children in divorced and remarried families.

Jackson, A.P. (2000). Maternal self-efficacy and children's influence on stress and parenting among single black mothers in poverty. Journal of Family Issues, 21, 3-16.

James, M.,K. (2016) investigated influence of type of single parenthood influences a student's self esteem from selected schools in Nakuru Municipality, Kenya IOSR Journal Of Humanities And Social Science (IOSR-JHSS) Volume 21, Issue 6, Ver. 4 (June. 2016) PP 14-16.

Manassis, K. (1996) Keys to parenting your anxious child. Hauppague, New York: Barron's Educational Series, Inc.

McKay, M., Fanning, P. (2000). Self-Esteem third edition, A proven program of cognitive techniques for assessing, improving and maintaining your self-esteem. Oakland, California: New Harbinger Publications, Inc.

Michelle, B. (2012). Types of Family Structure. http://www.afrointroduction.com/marriage. Retrieved March 17, 2018. 
Mursalin, M. (2019). The Critical Thinking Abilities in Learning Using Elementary Algebra E-Books: A Case Study at Public Universities in Indonesia. Malikussaleh Journal of Mathematics Learning (MJML), 2(1), 29-33.

Mintz, S., Kellog, S. (2016). Domestic Revolution, A Social History of America Family Life, New York, Free Press.

Moore, K.A., Vandivere, S., \& Redd, Z. (2006). A sociodemographic risk index. Social Indicators Research, 75, 45-81.

Muhammad T., A*, Muhammad A.(2016). Family Structure and Emotional Intelligence of Secondary School Students in Islamabad. American Journal of Educational Research, 2016, Vol. 4, No. 9, 685-688.

Niswah, U., \& Qohar, A. (2020). Mathematical Reasoning in Mathematics Learning on Pyramid Volume Concepts. Malikussaleh Journal of Mathematics Learning (MJML), 3(1), 23-26.

Nufus, H., \& Mursalin, M. (2020). Improving Students' Problem Solving Ability and Mathematical Communication through the Application of Problem Based Learning. Electronic Journal of Education, Social Economics and Technology, 1(1), 43-48. DOI: 10.33122/ejeset.v1i1.8

Nuraina, N., \& Mursalin, M. (2018). Improving Students' Mathematical Communication Skills Through Learning Start Learning Models With A Question on Pythagoras. Malikussaleh Journal of Mathematics Learning (MJML), 1(2), 44-47.

DOI: https://doi.org/10.29103/mjml.v1i2.2231

OECD/UNESCO-UIS (2003). Family Background and Literacy Performance.

http://www.oecd.org/dataoecd/43/9/33690591.pdf. retrieved May 9, 2016.

Parisa, R.(2011). The relationship between self-esteem, achievement goals and academic achievement among the primary school students. Procedia - Social and Behavioral Sciences $29,803-808$

Peter, B.N. (2016). Analysis of Family Structure Influence on Academic performance Among Secondary School Students in Bungoma East Sub-County, Kenya. International Journal of Secondary School education. 4(2), 12 - 22. http://www.sciwncwpublishinggroup.com/j/ijsedu.2016 0402.11. Retrieved May 9, 2018.

SAGE Publications. London, Thousand Oaks and New Delhi, Vol.10 (2): 217-236.

Shokraii, N.H. (2000). The self-esteem fraud: Why feel-good education does not lead to academic success. Center For Equal Opportunity. Retrieved June 2010 from http://www.users.interport.net/r/e/readinst/self.html.

Stone, A. (2012). Changing Patterns in Family Structure: The Plight of Children in Nigerian Schools. Macmillan Publishers Ltd., Nigeria. 